\title{
Wstęp
}

\section{Niewspólna. Kilka uwag o ojczyźnie}

\section{Przemysław Czapliński}

TEKSTY DRUGIE 2021, NR 3, S. 7-16

DOI: $10.18318 /$ td.2021.3.1 | ORCID: 0000-0002-4805-6471

W połowie 1981 roku, w zenicie doświadczenia solidarnościowego, ukazał się esej Jana Józefa Lipskiego Dwie ojczyzny, dwa patriotyzmy'.

Autor - zacznijmy od uproszczenia - mówił w nim, że polski patriotyzm ma swoją ciemną odmianę, która czerpie siłę z megalomanii i ksenofobii. Mroczny sobowtór, „Pan Ukryty” polskiej świadomości patriotycznej zamyka społeczeństwo w poczuciu wyższości bądź nienawiści wobec sąsiadów.

Esej opierał się na prostym koncepcie geograficznym: autor podejmował wyprawę naokoło Polski - do sąsiadów (Niemców, Rosjan, Czechów, Ukraińców, Litwinów, Białorusinów) i przedstawiał wpływy kulturowe, które z sąsiedztwa wynikały. Wspominał więc o wschodniej Cerkwi, prawosławiu i malarstwie ikonicznym, które polska kultura zawdzięcza kulturze rosyjskiej, o Biblii, która przyszła do nas za pośrednictwem języka

1 Pierwsze wydanie: Niezależna Oficyna Wydawnicza, Warszawa [czerwiec] 1981; pierwszy przedruk: „Kultura” (Paryż) 1981 nr 10, s. 3-29. W niniejszym tekście opieram się na wydaniu: J.J. Lipski Dwie ojczyzny, dwa patriotyzmy, w: tegoż Tunika Nessosa i inne eseje, Warszawa 1992. Tekst jest również dostępny online: http://otwarta.org/wp-content/ uploads/2011/11//-Lipski-Dwie-ojczyzny-dwa-patriotyzmy-lekkie3.pdf (10.05.21).

\section{Przemysław}

Czapliński - historyk literatury XX i XXI wieku, eseista, tłumacz; współtwórca Zakładu Antropologii Literatury (UAM Poznań). Ostatnie publikacje: Polska do wymiany (2009), Resztki nowoczesności (2011), Literatura ustna (2011), Kamp. Antologia przekładów (współredaktor A. Mizerka, 2013), Poetyka migracji (wespół z Renatą Makarską i Martą Tomczok, 2013), Poruszona mapa (2016). 
czeskiego, o prawach miejskich i porządku zabudowy miast, które przywędrowały z Niemiec... Po lekturze eseju Lipskiego czytelnik nie mógł już twierdzić, że istnieje coś takiego, jak „czysto polska kultura". Zarazem czytelnik ów nie powinien był odczuwać z tego tytułu żadnego wstydu - przeciwnie, mógł poczuć satysfakcję, poznając kulturę otwartą i zdolną przetwarzać treści importowane.

Megalomania potrzebuje jednak wartości czystych i tożsamości odizolowanych. Dlatego nakazuje wyśmiewać się z Czechów, pogardzać prymitywnymi Rosjanami, Ukraińcami i Białorusinami. Z kolei ksenofobia nieprzerwanie odtwarza nienawiść do Niemców, wypomina okrucieństwo Ukraińcom, reprodukuje agresywne uprzedzenia wobec Żydów. Obie emocje dobrze ze sobą współpracują we wzmacnianiu granic: ksenofobia szepcze, że Rosjanie, Ukraińcy czy Żydzi są z natury źli, megalomania podpowiada zaś, że my nie mogliśmy ich mordować, ponieważ jesteśmy na to zbyt wielcy i wspaniali. „Ksenofobia i megalomania wzajemnie się żywią i wspierają" (s. 143), dostarczając sobie energii i uzasadnień, które pozwalają Polakom żyć w poczuciu moralnej niewinności.

Niebezpieczeństwo, jak pokazywał Lipski, polega na tym, że obie emocje co prawda silnie wiążą wspólnotę, ale więź ta obraca się przeciw narodowi: jeśli łatwo można odświeżyć ksenofobię, to znaczy, że nietrudno sterować zbiorowymi emocjami. Po zakończeniu II wojny władze PRL często podgrzewały antygermańskie nastroje, by kogoś wykluczyć lub zakryć rzeczywiste problemy; narzucana miłość do ZSRR wywoływała pogardę dla Rosjan i rosyjskości, co powodowało, że "polskość" nie była zdolna odkryć rosyjskich składników we własnej kulturze i nie potrafiła porozumieć się z samą sobą. Megalomania i ksenofobia to zatem nie tylko odtrącenie tego, co obce, lecz przede wszystkim zakreślenie wąskich granic temu, co swojskie. Wspólnota odcinająca się od obcości potrafi nazwać swoją tożsamość tylko o tyle, o ile potrafi powiedzieć, kim i z kim nie chce być. Zbiorowość taką określa lęk przed „zmieszaną” tożsamością, przetwarzany w agresję wobec tego, co "obce".

Patriotyzmowi opartemu na resentymencie autor przeciwstawiał odnaleziony w tradycji polskiej patriotyzm krytyczny². Zróżnicowane jego artykulacje znajdował w dziełach Żeromskiego, Wajdy, Miłosza, w liście biskupów polskich do biskupów niemieckich z 1965, w kazaniu ks. Jana Ziei poświęconym Litwie, Białorusi i Ukrainie³.

2 Przy całej szlachetności celu i wywodu należy zauważyć, że autor: 1) spojrzał na polską kulturę z perspektywy, która przynależy wyłącznie inteligencji (sumarycznie, bez konkretnego regionalnego zakorzenienia); 2) posłużył się podziałem dychotomicznym, który zawsze upraszcza świat (i nie dopuszcza myśli, że postawy życiowe mogą się przenikać).

3 W kazaniu tym (wersja drukowana: ks. J. Zieja W rocznicę 17-go Września, „Kultura” [Paryż] 1974 nr 11) autor mówił: „Mamy obowiązek przede wszystkim przebaczyć wszystkim tym, do których żywiliśmy gniew, przebaczyć wszystkie krzywdy osobiście nam wyrządzone. Ale czy można mówić o tym, by jeden naród wybaczył drugiemu narodowi? Tak, to możliwe, ale my tu zebrani na 
Patriotyzm ten zasadza się na gotowości do przeprowadzania gorzkich obrachunków, czyli uwzględniania zarówno dobrych, jak i złych czy nawet najgorszych czynów wspólnoty ojczyźnianej. Jest też otwarty na pojednanie - gotów do wybaczenia pozwalającego na oczyszczenie się z poczucia krzywdy, nienawiści czy odrazy. Patriotyzm refleksyjny nie ucieka przed obowiązkiem kochania ojczyzny, ale pyta zawsze, do jakich czynów owa miłość chce nas prowadzić i kto z owej miłości może zostać wyłączony. Nie kwestionuje zatem dokonań heroicznych, lecz nie godzi się na to, by przeszłość redukowano do spisu zwycięstw; obok źródeł dumy stawia przedmioty wstydu i hańby.

Lipski przekonywał w eseju, że każde wymazywanie dawnego zła czynionego obcym, a także negowanie wpływów obcych kultur prowadzi do tworzenia wspólnoty opartej na zakłamaniu i nienawiści. Megalomania i ksenofobia nie są bowiem wyłącznie uczuciami żywionymi wobec obcości - stanowią projekt relacji wewnątrz samej wspólnoty. Ich istotą jest podporządkowanie wszystkich członków jednolitemu modelowi tożsamości, pozwalającemu zarządzać społeczeństwem za pośrednictwem prostych impulsów.

Esej Dwie ojczyzny należy do tych nielicznych tekstów, które poszerzają granice tekstualności, stając się działaniem. Jego zawartość, niewyrafinowana, ale doniosła, prosta, ale mądra, sprawiła, że tekst pozostał żywotny. Nie musi wracać, bo cały czas jest.

Żywotność ta była widoczna w licznych nawiązaniach, które pojawiły się rychło po opublikowaniu eseju. Jednakże w latach 80. w ujmowaniu relacji „ojczyzna - patriotyzm" nastąpiła dość istotna zmiana. Patriotyzm, łączony coraz wyraźniej z modelami polityczności, był testowany nie w kontekście tolerancji, lecz w odniesieniu do modernizacyjnej i demokratycznej skuteczności. Podejście takie napotkamy w Polityce i odpowiedzialności (1984) Jacka Kuronia, Trzech patriotyzmach Andrzeja Walickiego (1985) czy Szansach polskiej demokracji Adama Michnika (1987). Kluczową rolę odgrywały style politycznego myślenia, pozwalające połączyć rodzime tradycje kulturowe - zwłaszcza romantyzm - z wyczekiwaną demokracją. Być może trzeba było ciężkich doświadczeń lat 9o. - bezrobocia, eksmisji z mieszkań, gwałtownych rozwarstwień majątkowych, nawrotu nacjonalizmu i ksenofobii - by kategoria "ojczyzny" odzyskała znaczenie.

Pod koniec ostatniej dekady XX wieku Marcin Król napisał: „Niszcząc patriotyczny banał, niszczy się równocześnie patriotyczny odruch"4. Pomysł Lipskiego powracał więc

nabożeństwie żałobnym nie jesteśmy upoważnieni do podejmowania takich aktów. [...] Dziś tu zebrani możemy chyba tylko to powiedzieć, że jesteśmy głęboko spragnieni pojednania się naszego narodu z tamtym narodem".

4 M. Król Romantyzm. Piekło i niebo Polaków, Fundacja Res Publica, Warszawa 1998, s. 80. 
- choć w polemicznym ujęcius. Dla autora Dwóch ojczyzn patriotyzm wymagał współpracy rozumu z emocjami: sam rozum produkuje zimne, idealistyczne i najczęściej protekcjonalne wersje patriotyzmu, z kolei kiedy rozum śpi, budzą się emocjonalne upiory w postaci banałów, a wśród nich najsilniejsze zawsze okazują się negatywne stereotypy na temat "obcych"i wzniosłe stereotypy na temat "swoich". Dlatego Lipski wprowadzał kategorie chrześcijańskie - miłości bliźniego, troski, wybaczenia ${ }^{6}$ - jako nadrzędne wobec patriotyzmu. Według Króla natomiast nie można uprawiać dobrej polityki bez patriotyzmu i nie można ożywić patriotyzmu bez banału. Co więcej, musi to być banał podniosły, zamaszysty, a przynajmniej krzepiący, aby mógł wykarmić dumę. Bo patriotyzm pozbawiony dumy czy tworzony w opozycji do niej zanika, a razem z nim znikają więzi społeczne. W tej ekonomii afektywnej, zdaniem Króla, należy akumulować wszystko, co w dumę daje się przekształcić - wielkie zwycięstwa, średnie sukcesy, skromne osiągnięcia, a nawet umiejętność unikania skrajności. W największym skrócie zatem zaoczny spór między Lipskim a Królem polegałby na tym, że Lipski uważał megalomanię za trucicielski składnik patriotyzmu, natomiast Król za składnik konieczny. Niezbędny, choć niestanowiący kapitału wyłącznego czy ostatecznego.

Uczestników debaty na temat polskiego patriotyzmu z pewnością było więcej8, ale różnica zdań między wspomnianymi oponentami wskazuje na kluczowy problem - niemożność prostego oddzielenia patriotyzmu krytycznego od megalomańskiego. Megalomania tkwi bowiem w obu. Trzeba przecież mieć w sobie jakąś wizję wielkości ojczyzny, aby rodaków mobilizować do wysiłku, szlachetności czy tworzenia nowej historii. Bez megalomanii nie powstałoby „Posłanie do ludzi pracy Europy Wschodniej”,

5 Król nie cytuje Lipskiego, trudno jednak nie zakładać, że do Dwóch ojczyzn nawiązywał, gdy - raczej bez oparcia w badaniach socjologicznych - pisał: „Nie jesteśmy społeczeństwem ksenofobicznym ani zamkniętym, w znacznej większości nie chcemy ustaw penalizujących zasadnicze nawet decyzje moralne, nie żywimy nienawiści ani do Rosjan, ani do Niemców, ani do Ukraińców, ani do nikogo w szczególności, a już na pewno nie w rozmiarach, jakie usprawiedliwiałyby dramatyzowanie i rozdzieranie szat" (tamże, s. 82).

6 O cnotach kardynalnych respektowanych przez Lipskiego w życiu i pisaniu zob. Ł. Garbal Świat wartości „prezydenta polskiej opozycji” (w niniejszym numerze).

7 „Jest [...] najzupełniej pewne, że rekonstrukcja ojczyzny musi się dokonać na podstawie dumy i pamięci, że jest to zadanie dla nas wszystkich, ale w szczególności zadanie dla inteligencji polskiej [...]" (M. Król Romantyzm. Piekło i niebo Polaków, s. 84).

8 W kolejnej dekadzie - np. W obronie zdrowego rozsq̨dku, red. M.A. Cichocki, T. Merta, Ośrodek Myśli Politycznej i Księgarnia Akademicka, Kraków 2000; A. Hall Jaka Polska?, Rosner \& Wspólnicy, Warszawa 2004; J. Kuroń Rzeczpospolita dla moich wnuków, Rosner \& Wspólnicy, Warszawa 2004; M. Król Patriotyzm przyszłości, Rosner \& Wspólnicy, Warszawa 2004; M.A. Cichocki Władza i pamięć. O politycznej funkcji historii, Ośrodek Myśli Politycznej i Wyższa Szkoła Europejska im. księdza Józefa Tischnera, Kraków 2005. 
zestawione przez Krzysztofa Obremskiego z esejem Lipskiego9. Żeromski w Przedwiośniu upokorzył Cezarego Barykę ojczyźnianym błotem, ale zostawił mu „szklane domy”, w których mogłaby zamieszkać odnowiona wspólnota. Brzozowski kpił z Polski zdziecinniałej, bo marzył o Polsce dorosłej, w której historia jest świadomie wytwarzana, a nie traktowana jako "stan natury".

Lipski - choć zaniepokojony megalomanią - mimowolnie odsłonił jej pociągający aspekt, gdy stwierdzał: „Strzeżmy się i podejrzliwie patrzmy na każdą nową kampanię «patriotyzmu» - jeśli jest bezkrytycznym powielaniem ulubionych sloganów megalomanii narodowej. Za frazeologią i rekwizytornią miłą przeważnie Polakowi - czają się najczęściej cyniczni socjotechnicy, którzy patrzą, czy ryba bierze - na ułańskie czako, na husarskie skrzydło, na powstańczą panterkę"(s. 141). Słowa są arcytrafne. Ale skrywa się w nich pewna zagadka. Krytycyzm postulowany przez Lipskiego nakazywałby przecież zapytać, dlaczego „ryba” bierze na „powstańczą panterkę", a nie na "gorzką tradycję obrachunków" (s. 141)? Dlaczego, mówiąc skrótowo, Żeromski przegrywa z Sienkiewiczem? Czy nie dlatego właśnie, że patriotyzm potrzebuje wielkości, a wariant krytyczny, choć bardzo tego pragnie, nie potrafi jej dostarczyć? Przypuszczenie, że nawet patriotyzm krytyczny szuka wielkości, potwierdza sam Lipski, gdy, z koniecznym zastrzeżeniem i niejakim zakłopotaniem, pisze: „Myślę, że bez megalomanii narodowej można twierdzić, że Europa dużo traci przez faktyczną nieznajomość Mickiewicza, Słowackiego, Norwida. Zna natomiast już stosunkowo nieźle Gombrowicza i Witkacego" (s. 162). Z tego wyliczenia wyłania się wniosek, że niemożliwy jest patriotyzm odmawiający zaspokajania zbiorowej potrzeby wielkości. Potrzeba ta jest tak silna, że źródłem dumy musi się stać krytycyzm. Problem polega na tym, że wówczas patriotyzm krytyczny przestaje być krytyczny.

\section{Korekty mniejszościowe}

W dyskusji na temat ojczyzny ważniejsza od normatywnej definicji patriotyzmu wydaje się analiza warunków jego tworzenia. Pytania „Czym jest? Jaki powinien być?" nie wystarczają. Konieczna jest refleksja nad tym, skąd się bierze.

Odpowiedź wydaje się prosta: zewsząd. Kształtują go prymarne instytucje socjalizujące jednostkę ludzką, czyli dom, szkoła, kościół, środowisko rówieśnicze. A także media - nie tyle działające po szkole, po domu i kościele, ile przed nimi, z nimi, równocześnie, nieustannie. Filmy, teksty piosenek, transmisje sportowe, informacje gospodarcze i polityczne - wszystkie te elementy kultury codziennej kształtują patriotyzm, ten zaś zwrotnie wzmacnia schematy myślowe i językowe. A schematy te, o czym pisze

9 Zob. w niniejszym numerze, s. 48. Autor zestawia esej Lipskiego z „Posłaniem do ludzi pracy Europy Wschodniej" sformułowanym na I Zjeździe Delegatów NSZZ "Solidarność" (wrzesień 1981). 
Michał Rusinek, organizują postrzeganie świata, nadają spójność poglądom i dostarczają wartościowań10.

Wynika z tego, że patriotyzm istnieje dzięki inżynierii społeczno-politycznej, którą stosują zarówno instytucje, jak i zwykli ludzie. Nic nie jest w tej socjotechnice neutralne, wszystko natomiast jakieś potrzeby zaspokaja, a inne tłumi. Różnica między jednym i drugim daje się odczytać z analizy korekty mniejszościowej, czyli interpelacji zgłaszanych przez grupy słabiej reprezentowane, pozbawione części praw, marginalizowane czy dyskryminowane.

Tak rozpatrywany patriotyzm polski ostatnich trzech dekad układa się $\mathrm{w}$ dramatyczny spór. W latach 9o. dyskurs dominujący profilował patriotyzm zgodnie z wąsko pojętą demokracją i liberalizmem. Być patriotą znaczyło uczestniczyć w wyborach, płacić podatki i dążyć do indywidualnej samodzielności odciążającej państwo. Jednak w tym samym czasie korekta mniejszościowa wprowadzała do debaty publicznej kolejne tożsamości nieprawomocne.

Czy mieszczą się one w eseju Dwie ojczyzny? Nie chodzi o to, czy zostały wymienione, lecz o to, czy mogą zostać dopisane do "my" zastosowanego przez autora.

Niemożności przeprowadzenia takiej operacji dowodzi esej Agnieszki Graff'1 dotyczący skutków pominięcia płci i utożsamienia katolicyzmu z chrześcijaństwem. W kontekście rozważań Agnieszki Graff można powiedzieć, że po roku 1989 ojczyzna konsekwentnie okazywała się rodzaju męskiego. Z ojczyzny tej kobiety są systematycznie wypychane. Po zaostrzeniu przepisów antyaborcyjnych przegłosowanym przez Sejm RP w roku 1993 rozpoczęła się historia prawnego blokowania kobietom dostępu do symboli narodowych. Nie wolno wrysować kropek symbolizujących piersi w znak kotwicy, nie wolno używać hasła „Polki Walczące” ani stosować hasła „Polki Wyklęte”. Wykorzystywanie (parafrazowanie) symboliki heroicznego oporu jest zabronione. Kobiety mogą być patriotkami tylko wtedy, gdy zakryją swoją płciowość i związane z nią żądania12. Jeśli Lipski pisał o dwóch ojczyznach, to z perspektywy kobiet jest ona prawdopodobnie jedna - przyznająca obywatelstwo w zamian za podległość.

Równie dramatycznie przedstawiają się spory o miejsce w ojczyźnie osób nieheteronormatywnych. Jedną z ostatnich kulminacji była polemika wokół Kamieni na szaniec.

10 Zob. w niniejszym numerze: M. Rusinek Między antytezą i enumeracja, czyli dwie wersje prefigurowania polskiej rzeczywistości. Szersze omówienie zob. K. Kłosińska, M. Rusinek Dobra zmiana, czyli jak się rządzi światem za pomocą słów, Znak, Kraków 2019. Zob. w niniejszym numerze: A. Graff „Nikt nie widział w tym niczego szczególnego."O kilku przeoczeniach i uniwersalizacjach w „Dwóch ojczyznach”| Jana Józefa Lipskiego i co z nich wynika. ujęła w metaforę militarną, zob. tejże To jest wojna. Kobiety, fundamentaliści i nowe średniowiecze, Agora, Warszawa 2020. 
W 2013 roku Elżbieta Janicka w wywiadzie udzielonym Polskiej Agencji Prasowej³ zwróciła uwagę na dwa symptomatyczne pominięcia w recepcji książki Aleksandra Kamińskiego. Nikt mianowicie nie zauważył, po pierwsze, że powieść - ważna lekcja patriotyzmu martyrologicznego w powojennych kanonach lektur - ukazuje Warszawę czasów okupacji bez getta, Żydów i ich powstania ${ }^{14}$. Po wtóre, Janicka skierowała uwagę na specyfikę chłopięcej przyjaźni między "Rudym"a „Zośką", członkami oddziałów Szarych Szeregów; gesty i czułość określające tę przyjaźń, wyraźnie akcentowana potrzeba bliskości i dotyku, serdeczność i namiętność słów nadają tej relacji charakter homoerotyczny (nie - homoseksualny!).

Odpowiedzi na interpretację Janickiej były liczne, lecz z wyjątkami zasadniczo zgodne ${ }^{15}$ : wulgarny paszkwil Rafała Ziemkiewicza, protekcjonalny tekst Tomasza Lisa czy ironiczny felieton Krzysztofa Vargi łączyło przekonanie, że jakikolwiek homoerotyczny podtekst w relacji między "Zośką" a „Rudym” jest wykluczony. Oburzenie polemistów naprowadza na trop patriotyczny - w panteonie bohaterów, którzy oddali życie za ojczyznę, nie ma miejsca dla „pedałów". Śmierć śmierci nierówna, bohaterstwo hetero i homo nie ważą tyle samo, a poświęcenie dla Polski dopiero wtedy się liczy, jeśli towarzyszy mu świadectwo normatywnej seksualności' ${ }^{16}$.

Żaden racjonalny pogląd nie uzasadni takiego wykluczenia. Bo też nie rozum jest tu czynny. W sporze o Kamienie na szaniec ujawniła się siła działania odrazy. To ona wespół z afektami pokrewnymi, czyli wstrętem, obrzydzeniem i antypatią - odmawia obywatelstwa w ojczyźnie. Do koncepcji Lipskiego wprowadza to poważne zakłócenia, ponieważ dowodzi, że definicji ojczyzny nie da się racjonalnie wynegocjować. Uczestnicy debat zasiadają bowiem do dyskusji z afektami pulsującymi pod skórą. Kiedy dochodzi do sporu - a wybucha on zawsze przy okazji omawiania wzorców walki, wierności i umierania - patriotyzm odsłania swoje preferencje płciowe i seksualne. W polemice dotyczącej Kamieni na szaniec preferencje patriotyzmu krytycznego i megalomańskiego okazały się niestety zbieżne. Wynika z tego, że kobiety i nieheterycy nawet po osiągnięciu równouprawnienia nie zyskaliby pełnego obywatelstwa w ojczyźnie. Paszport ojczyźniany jest bowiem wystawiany nie przez prawo, lecz przez męskie afekty.

13 A. Szwedowicz Dr Janicka z PAN: mit "Kamieni na szaniec" domaga się analizy, https://dzieje.pl/ aktualnosci/dr-janicka-z-pan-mit-kamieni-na-szaniec-domaga-sie-analizy (1.05.2021).

14 Autorka pisała o tym już we wcześniejszej książce, zob. tejże Festung Warschau, Wydawnictwo Krytyki Politycznej, Warszawa 2011.

15 Pełne omówienie sporów o powieść - od 1944 do 2013 roku - zob. S. Karolak Spory o „Kamienie na szaniec"Aleksandra Kamińskiego, Poznańskie Towarzystwo Przyjaciół Nauk, Poznań 2019.

16 Z tego samego powodu homoseksualni więźniowie nazistowskich obozów koncentracyjnych nie są w polskiej kulturze zaliczani do pełnoprawnych ofiar II wojny światowej, zob. J. Ostrowska Oni. Homoseksualiści w czasie Il wojny światowej, Wydawnictwo Krytyki Politycznej, Warszawa 2021. 
Ich wpływ odzywa się w biografii jeszcze jednego podmiotu zbiorowego - klasy ludowej. Od stuleci dobija się ona o pełnię obywatelstwa w ojczyźnie. Od dekady umowną granicę wyznacza spektakl Wimię Jakuba S. (2011) Pawła Demirskiego w reżyserii Moniki Strzępki - towarzyszy temu delegitymizacja „pańskiej” (szlacheckiej, ziemiańskiej, częściowo inteligenckiej) wersji patriotyzmu. „Zwrot ludowy" w badaniach ${ }^{\mathbf{7}}$ - nie moda, nie doraźne zainteresowanie czy koniunktura grantowa, lecz poważny nurt rewizjonistyczny - przynosi coraz więcej "gniewnych" monografii, które analizują kluczowe mity legitymizujące panowanie ${ }^{\mathbf{1 8}}$. Monografie te, choć merytorycznie dotyczą „sprawy chłopskiej", korygują całą debatę o ojczyźnie.

Nakazują one uwzględnić rolę pogardy w historii Polski. W refleksji Lipskiego ksenofobia i megalomania były wytworami histerii patriotycznej, która reaguje fobią i manią na „ciała obce". Histeryczny nacjonalista, zatrwożony niedoborem wypracowanego przez Polaków bogactwa i nadmiarem wyrządzonych przez nich krzywd, polonizuje cudze wpływy kulturowe i wybiela winy własne, zyskując w ten sposób wyidealizowany portret narodu. Można fobie i manie potraktować jako rezultat niedoboru rozumu, choć zarazem nie sposób odmówić temu egoizmowi pewnej logiki, która chce całą "miłość” zachować dla „swoich", a całą nienawiść - dla „obcych". Pogarda wobec chłopów jest wszakże podszyta lękiem przed upadkiem w niższość, lękiem skrywanym przez opiekuńcze wersje patriotyzmu. Analiza musi tu więc uwzględnić nie tylko konstruowane tożsamości i wynikające stąd hierarchie, lecz także klasową inżynierię afektywną, czyli procesy kulturowe zaszczepiające odrazę do chłopa jako składnik miłości do ojczyzny.

Wiąże się z tym kwestia druga. Ksenofobia i megalomania w ujęciu Lipskiego były prewencją stosowaną wobec "obcych" - Rosjan, Żydów, Niemców czy Ukraińców. Tymczasem chłop to „podporządkowany swój"19, a historia chłopstwa to dzieje konstruowania "wewnętrznego obcego"; chłopa od XIX wieku uznawano za "ostoję polskości", a jednocześnie lepiono go z cech maksymalizujących różnicę w podobieństwie. Chłopi

17 Zob. P.W. Ryś Zwrot plebejski we współczesnej humanistyce i debacie publicznej, w: Historia, interpretacja, reprezentacja, t. 3, red. L. Mokrzecki, M. Brodnicki, J. Taraszkiewicz, Athenae Gedanenses, Gdańsk 2015.

18 Wymienić tu trzeba przynajmniej książki autorskie: W. Marzec Rebelia i reakcja. Rewolucja 1905 roku i plebejskie doświadczenie polityczne, Wydawnictwo UŁ i Universitas, Łódź-Kraków 2016; M. Rauszer Bękarty pańszczyzny. Historia buntów chłopskich, Wydawnictwo RM, Warszawa 2020; P. Korczyński Śladami Szeli, czyli diabły polskie, Wydawnictwo RM, Warszawa 2020; A. Leszczyński Ludowa historia Polski. Historia wyzysku i oporu. Mitologia panowania, W.A.B., Warszawa 2020; K. Pobłocki Chamstwo. Ludowa historia Polski, Czarne, Wołowiec 2021; M. Rauszer Siła podporząkowanych. Antropologia chłopskiego oporu czasów pańszczyzny XVI-XIX wieku, Wydawnictwa UW, Warszawa 2021.

19 Parafrazuję określenie stworzone przez Gayatri Chakravorty Spivak, zob. tejże Czy podporzq̨dkowani inni moga przemówić?, przeł. E. Majewska, „Krytyka Polityczna” 2010 nr 24/25, s. 196-239. 
podlegali więc wkluczającemu wykluczeniu, stanowiąc fundament struktury klasowej nie tylko jako konkretna klasa społeczna, lecz także jako warunek umożliwiający tworzenie hierarchii. Przez pięćset lat w polskiej historii chłopstwo było laboratorium wytwarzania różnicy wewnętrznej. Lipski przekonuje, że ksenofobia pomagała zdefiniować polskość $w$ relacji do świata zewnętrznego; badania nad pańszczyzną pokazują, że społeczny porządek wewnętrzny opierał się na chamofobii² ${ }^{20}$.

I wreszcie, po trzecie, historia chłopstwa - podobnie jak historia kobiet - to dzieje wyzysku. Jak pisze Adam Leszczyński w monografii Ludowa historia Polski:

W istocie całą wewnętrzną historię Rzeczypospolitej można [...] opowiedzieć z perspektywy wysiłków elity o zdobycie jak największego udziału w podziale wypracowanego społecznego produktu. [...] pozostałe 90 proc. ludności Rzeczypospolitej chłopi, mieszczanie iżydzi - próbowało dostosować się do życia w stanie podległości, chroniąc równocześnie jak największą część tego, co sami mogli wyprodukować. ${ }^{21}$

Badania chłopskiej podległości wprowadzają wątek zysku, który determinuje ekonomiczną analizę relacji panujących w ojczyźnie. Równie istotne jako przedmiot badań okazują się, nieodłączne od zysku, narracje patriotyczne, które legitymizowały poddaństwo. W tym kontekście sprawdzianem dla patriotyzmu krytycznego nie może być już tylko wrażliwość na wykluczenie obcych.

\section{Wspólne pytania}

Ojczyzna implikuje jedność. Tytuł eseju Lipskiego alarmował, bo sygnalizował zagrożenie czające się w podwojeniu. Ale jedność rozpada się również wtedy, gdy "podporządkowani swoi"zaczynają mówić.

Czy właśnie z tym mamy do czynienia w Polsce? Czy tracimy wspólną ojczyznę, ponieważ coraz więcej podmiotów zbiorowych - nie godząc się z niesprawiedliwością i niesolidarnością ojczyzny i nie mogąc się w niej odnaleźć - ogłasza swoją wyprowadzkę? Ale może społeczeństwu nie jest potrzebna jedna ojczyzna? Może poszczególne grupy powinny móc tworzyć swoje ojczyzny alternatywne, a dobrem wspólnym niech pozostanie państwo prawa, w którym rząd stosuje konstytucję, honoruje rozdział domeny świeckiej od kościelnej, strzeże granicy oddzielającej władzę wykonawczą od sądowniczej i nie upartyjnia mediów publicznych? W państwie prawa reprezentację

20 Zob. P.W. Ryś Chamofobia jako składnik polskiej kultury.Zarys problematyki."Czas Kultury”2016 nr 4. 
kulturową i polityczną gwarantują inne środki niż ekonomia symboliczna właściwa ojczyźnie.

Powyższą kwestię - rozstania z jedną ojczyzną - ośmielam się dodać do pytań już postawionych. Te wcześniejsze dotyczyły możliwości istnienia patriotyzmu bez dumy i niemożliwości debatowania dzisiaj o patriotyzmie bez zwracania uwagi na płeć, seksualność i przepływy kapitału wśród mieszkańców ojczyzny. Taka hermeneutyka patriotyzmu, czerpiąca inspiracje z eseju Jana Józefa Lipskiego, jest zarazem dopowiedzią (do artykułów pomieszczonych w niniejszym zeszycie „Tekstów Drugich"), jak i ewentualnie zapowiedzią. Temat jest ważny, toteż nasze łamy i dyskusja pozostają otwarte. Dyskusja będzie oznaczała, że ojczyzna trzyma się na wspólnych pytaniach.

\section{Abstract}

\section{Przemysław Czapliński}

ADAM MICKIEWICZ UNIVERSITY (POZNAŃ)

Not Inclusive: A Few Remarks on the Homeland

This article discusses Jan Józef Lipski's essay Dwie ojczyzny, dwa patriotyzmy [Two Homelands, Two Patriotisms] as a matrix of patriotism. The main question is: will the homeland designed by Lipski accommodate illegitimate identities (woman, gay, peasant) that can be described as "subordinated familiars" (or "internal strangers")? Czapliński concludes by asking whether we still need the "homeland" today.

\section{Keywords}

homeland, patriotism, megalomania, xenophobia, critical patriotism, illegitimate identities, subordinated familiar, internal stranger. 